\title{
A note on the periphrastic past in Afrikaans
}

\author{
Jan-Wouter Zwart \\ Center for Language and Cognition Groningen, University of Groningen, The Netherlands \\ E-mail: c.j.w.zwart@rug.nl
}

\begin{abstract}
The periphrastic past tense of Afrikaans, involving the auxiliary het, is compared with its ancestor construction in Dutch. I argue that the situation in Afrikaans provides support for the analysis of Germanic verb clusters in Zwart (2017), where periphrastic verb forms occupy cells in morphological paradigms, and enter the syntax only after the syntactic derivation has run its course.
\end{abstract}

Keywords: minimalism, periphrasis, periphrastic past, auxiliary, lexicalism, Afrikaans, Dutch

\section{Introduction}

The verbal morphology of Afrikaans, in comparison with Dutch, shows the advanced deflexion typical of creole languages, but, unlike creole languages, Afrikaans did not develop analytical markings for tense, mood, and aspect. Instead, Afrikaans uses modal and voice auxiliaries of recognizable Dutch origin, as well as the typical Germanic periphrastic past tense expressed by a past participle and the auxiliary het ( $<$ Dutch heeft, dialectal het, "has"). As a result, Afrikaans appears to have verb clusters of a type sufficiently similar to Dutch for them to be routinely included in the discussion of Continental West Germanic verb clusters (e.g. Robbers 1997, Schmid 2005). Here, I reconsider the similarities and differences between Dutch and Afrikaans in this domain, and note how the facts of Afrikaans lend support to the analysis of periphrasis and verb clusters of Zwart (2018).

\section{Synthesis vs. periphrasis in Afrikaans and Dutch}

Morphologically, Afrikaans verbs show an opposition between an unmarked form and a periphrastic past tense form:

$$
\begin{aligned}
& \text { a. ... dat ek werk. } \\
& \text { cOMP 1SG work } \\
& \text { "... that I am working." } \\
& \text { b. } \quad \text {... dat ek ge-werk het. } \\
& \text { cOMP 1SG GE-work AUX } \\
& \text { "... that I have worked." }
\end{aligned}
$$


The lexical verb werk "work" in (1a) and the auxiliary het in (1b) are both unmarked and invariable, expressing no agreement of any kind. Likewise, werk and het have no synthetic past tense form (and in fact gewerk het is used for the pluperfect as well; Donaldson 1993: 231).

Dutch verbs, in contrast, show a two-way binary tense opposition (cf. Verkuyl 2008), opposing present to past and synthetic to analytic:

$$
\begin{aligned}
& \text { a. ...dat ik werk/werk-te. } \\
& \text { COMP 1SG.SU work work-PST.SG } \\
& \text { "... that I'm working/worked." } \\
& \text { b. ...dat ik ge-werk- } t \text { heb /had. } \\
& \text { COMP 1SG.SU GE-WORK-D AUX:1SG AUX:PST.SG } \\
& \text { "... that I worked / had worked." }
\end{aligned}
$$

The periphrastic past tense in Dutch (2b) is a relative tense, positioning the event before a reference point (which may be the here and now, or a point in the past) (Zwart 2011: 12). The simple past in (2a), on the right, expresses cotemporaneity with a reference point in the past. This opposition between anteriority and cotemporaneity is lost in Afrikaans.

\title{
3. Finiteness
}

Interestingly, the anteriority/cotemporaneity opposition in Dutch is only relevant in finite contexts. In infinitives, the periphrastic expression is used for both cotemporaneous and anterior past:

\author{
a. Hij beweer-t ge-slap- en te heb-ben \\ 3SG.SU claim- 3SG GE- sleep- D INF AUX-INF \\ (toen /voor) ik binnen kwam. \\ when before 1SG.SU in come:PST.SG \\ "He claims to have been asleep (when/before) I came in."
}

b. *Hij beweer-t te slap- en (toen/ voor) ik binne kwam.
3SG.SU claim- 3SG INF sleep-INF when before 1SG.SU in come

In (3), toen/voor ik binnen kwam "when/before I came in" provides the temporal reference point, and both cotemporaneity (with toen "when") and anteriority (with voor "before") vis-àvis the reference point require the use of the periphrastic infinitive.

The verbal system of Afrikaans, then, is identical to the reduced system of Dutch infinitives. In this connection it is interesting that the \pm finite opposition has all but disappeared in Afrikaans. Thus, next to (1) we get (4) (cf. Donaldson 1993: 247-248):

$$
\begin{aligned}
& \text { a. } \quad . \text { om te werk. } \\
& \text { COMP INF work } \\
& \text { "...to work" }
\end{aligned}
$$



b. $\quad$... om te ge-werk het
COMP INF GE-work AUX
"... to have worked"

The periphrastic past infinitive in (4b) can be used both to express cotemporaneity with a reference point in the past (5) and to express anteriority (6) ((5) adapted from Robbers 1997: 91; (6) from Donaldson 1993: 241).

(5) Diefliek skyn toe 'n sukses te ge-wees het. the movie seem then a sucess to GE-be AUX "The movie seems to have been a success then."

(6) Hy mag sy motor dalk al verkoop het. 3SG.M may 3SG.POSS car maybe already GE:sell AUX "He may already have sold his car."

The obligatory use of a particular form (the periphrastic infinitive with have) to accommodate temporal semantics indicates that tense may be present in nonfinite contexts. This shows that a simple characterization of finiteness in terms of tense will not do (Wiklund 2005; Nikolaeva 2007; Zwart 2014).

\section{Have}

Afrikaans het is derived from Dutch heeft "has" (dialectal het), infinitive hebben, a verb of possession commonly employed in the expression of the perfect in Indo-European (Vendryes 1937). Have may be decomposed into be + preposition (cf. Benveniste 1960), giving rise to syntactic analyses of auxiliary have as the result of a conflation of be with some other functional element (Kayne 1993; Zwart 1996; Hoekstra 1999).

Whatever the merits of this analysis for English and Dutch, it will not carry over to Afrikaans, where it can be shown that het is different from the possessive verb (hê). The possessive verb is one of the very few in Afrikaans that still shows a \pm finite opposition (Ponelis 1993: 411):
a. Hulle het geld.
3PL have money
"They have money."
b. Hulle sal geld hê.
3PL will money have:INF
"They will have money."

But the auxiliary het does not have a nonfinite variant hê (Malherbe 1917: 63-64; Ponelis 1993: 412):

(8) Hulle sou haar ge-sien (het/*hê ).

3PL will:PST 3SG.F.OB GE-SEE AUX AUX:INF

"They would have seen her." 
The construction in (8) is one where both finite and unmarked forms may typically appear, as shown in (9) with modal auxiliaries (another category where a past/unmarked opposition survives; note that the preferred variant is wou) (Donaldson 1993: 242):

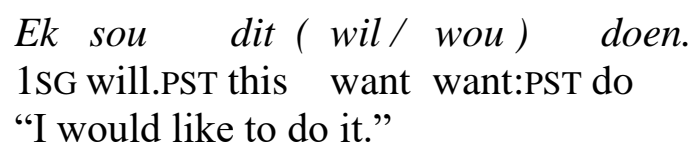

The fact that $h \hat{e}$ is nevertheless excluded in (8) suggests that het has become a designated past tense marker in Afrikaans (apparently alternating with the past tense adverbial toe "then", which seems to have assumed a similar function with unmarked verb forms; cf. Ponelis 1993: 432f).

\section{5. het vs. the Dutch auxiliary heeft}

On closer inspection, Afrikaans het differs from its ancester Dutch heeft in several other respects (data from Donaldson 1993; Robbers 1997). The following summary makes no claim of being comprehensive (thanks to the anonymous reviewers for various refinements and caveats):

(a) the past participle in Dutch can both precede (2b) and follow (heb gewerkt) the auxiliary; in Afrikaans. het invariably follows the participle

(b) in Dutch, the participle can "float" to a position to the left of a modal verb (gewerkt kan hebben "may have worked"); in Afrikaans, the past participle and the auxiliary must both follow the modal (kan gewerk het)

(c) in Dutch, the infinitival marker te has to immediately precede the nonfinite auxiliary (hoeft gezien te hebben "needs to have seen"); in Afrikaans, te has to precede the participleauxiliary combination (hoef te gesien het)

(d) in Dutch, three-verb strings, where the most deeply embedded verb is a bare infinitive, the order is 1-2-3 (where the higher number indicates deeper embedding), and the participle is replaced by an infinitive (heeft laten vallen "has dropped" [lit: has cause fall]); in Afrikaans, the auxiliary remains the final element, yielding the order 2-3-1 (gelaat val het), and the participle is not necessarily replaced by the unmarked form (one relevant factor being verb type)

(e) in similar verb strings with postural verbs, Dutch again has 1-2-3 (heeft zitten lezen "has been reading" [lit: "has sit read"]); in Afrikaans, where a hendiadys construction appears, the order is again 2-3-1 and ge-drop varies among speakers ((ge)sit en lees het)

(f) in Dutch, three-verb strings where the most deeply embedded verb is a te-infinitive, again the order is 1-2-3 (is begonnen te slaan "started to beat"); in Afrikaans, the order is once again 2-3-1 (begin (te) slaan het).

These observations indicate a much stronger interdependence between the participle and the auxiliary in Afrikaans than in Dutch, the auxiliary in Afrikaans approximating the status of a morphological appendage/suffix (as also argued earlier by Conradie 2007: 218). Analyzing het 
as a morphological appendage would account for its obligatory position directly following the participle. It would also make sense of the observation in (c) where the participle-auxiliary combination of Afrikaans appears to be in the scope of the infinitival marker $t e$.

Where the participle and het are not string-adjacent, as in (d) and (e), a case may be made for the participle to form a unit with the material separating it from the auxiliary, so that we get, for (d), the structure [ gelaat val] ]-het. That laat-val may be a unit in Afrikaans is suggested by the observation that this two-verb string behaves as a single element in (optionally) undergoing verb second (Biberauer 2013; example adapted from Ponelis 1979: 245):

(10) Hy laat val die strokiesprent.

3SG.SU let fall DET cartoon

"He drops the cartoon."

We find these "complex initials" also with the hendiadys construction of (e) (Robbers 1997: 65), though not, apparently, with verbs selecting a te-infinitive (f), or, in fact, with the participle-het complex, discrepancies I must leave for further study at this point.

\section{Morphology after syntax}

In an earlier article (Zwart 2018), I have argued that the periphrastic past in Dutch (see (2b)) must be viewed as the product not of syntax, but of morphology, in the sense that periphrastic verb forms are listed alongside synthetic forms in the verbal paradigms (following much recent research on periphrasis, cf. Chumakina and Corbett 2013).

This must be understood in the context of the model of grammar in current minimalism, where narrow syntax involves just structures and features, and lexical insertion is a postsyntactic operation supplying syntactic terminals with lexical items that match the inflectional features of the syntactic terminal (e.g. Halle and Marantz 1993). The "lexicalist" analysis of the periphrastic past contemplated in Zwart (2018) is intended as an alternative to the "syntactic" analysis, in which the auxiliary and the participle are separate elements in syntax, and receive separate spell-outs after narrow syntax. (The analysis is not entirely lexicalist in that I do assume a separate subderivation in which the periphrastic forms are put together via a regular syntactic structure building process.)

The string consisting of the participle and the element het in Afrikaans, with its rigid linear order and obligatory adjacency, shows even clearer signs of lexical status than its Dutch ancestor construction. The participle-het complex behaves as a unit, with a fixed order and adjacency of its component parts. On the analysis contemplated here, the periphrastic past fills one of the two cells in the Afrikaans morphological verb paradigm (identified by the single feature [PAST]), as in (11), and spells out a syntactic terminal marked by the same feature.

\begin{tabular}{|l|l|}
\hline UNMARKED & werk \\
\hline PAST & gewerk het \\
\hline
\end{tabular}

I believe that this analysis was never seriously considered before, for the very good reason that the auxiliary het shows signs of syntactic independence from the participle: it undergoes verb- 
second by itself. Compare (12a), with verb-second of het, to (1b), an embedded clause, where no verb-second takes place. (12b) shows that the auxiliary cannot pied-pipe the participle when it undergoes verb-second.
a. Ek het ge-werk.
1SG.SU AUX GE-work "I worked."
b. $\quad * E k \quad$ ge-werk het.
1SG.SU GE-work AUX

In addition, het shows independence from the participle in ellipsis, as in (13) (Donaldson 1993: 255-256).

(13) (Has he already done it?)
Ja, hy het.
yes 3SG.M.SU AUX
"Yes, he has."

But currently these observations no longer provide knock-down arguments for the independent syntactic status of the auxiliary. Ellipsis, in the current model of grammar, is most likely viewed as an interface phenomenon, representing a partial failure to lexicalize (e.g. Merchant 1999). Likewise, Chomsky (2001: 37) suggests that verb-second may be a postsyntactic linearization phenomenon, not to be regulated in narrow syntax (see also Conradie 2007: 218 for the idea that verb-second involving het is a late rule, applying after the formation of the participle-het complex). If so, the phenomena in (12)-(13) no longer argue for the syntactic status of auxiliaries, and the idea that periphrastic tense forms are morphological items may be seriously considered (Zwart 2018).

This leaves a number of interesting questions open (in particular, by what mechanism the auxiliary is singled out in verb-second and ellipsis), but in the context of this squib, these questions unfortunately have to be put aside.

\section{Conclusion}

I have argued that the properties of the periphrastic past in Afrikaans support a "lexicalist" analysis of periphrastic verbal morphology; more precisely, an analysis in which periphrastic forms occupy cells in morphological paradigms. The argumentation rests on the properties of the auxiliary element het, which is uninflected and unmarked for finiteness, and is obligatorily right-adjacent to the participle. The fact that het nevertheless undergoes verb-second is consistent with this analysis on the assumption of Chomsky (2001) that verb-second is a postsyntactic operation of linearization.

I submit that this analysis of the periphrastic past in Afrikaans calls for a re-evaluation of the mechanisms of verb clustering as they feature in the literature comparing Afrikaans and Continental West Germanic verb clusters (e.g. Robbers 1997). If the periphrastic past occupies a cell in the morphological paradigms, it is inserted in the position of a syntactic terminal as a 
single item. No syntactic operations, then, are needed to derive the 2-1 word order. The existence of these operations plays a major role in Robbers's (1997) analysis of verb clusters in Afrikaans, which now appears to be up for simplification, if I am correct.

I would like to close by expressing my appreciation for Johan Oosthuizen, a dear friend since his first visit here in Groningen twenty years ago, and a singular presence in the South African linguistics community throughout his career.

\section{References}

Benveniste, É. 1960. Être et avoir dans leurs fonctions linguistiques. Bulletin de la Société Linguistique, 55: 113-134.

Biberauer, T. 2013. Germanic verb clusters again with Afrikaans centre-stage. Paper presented at the 28th Comparative Germanic Syntax Workshop, Leipzig, October 4.

Chomsky, N. 2001. Derivation by phase. In M. Kenstowicz (ed.). Ken Hale: a life in language. Cambridge: MIT Press. pp. 1-52.

Chumakina, M. and G. Corbett (eds). 2013. Periphrasis: the role of syntax and morphology in paradigms. Oxford: Oxford University Press.

Conradie, J. 2007. The final stages of deflection: the case of Afrikaans het "have". In J. Salmons and S. Dubenion-Smith (eds). Historical Linguistics 2005. Selected papers from the 17th International Conference on Historical Linguistics, Madison, Wisconsin, 31 July - 5 August 2005. Amsterdam: Benjamins. pp. 207-221.

Donaldson, B. 1993. A grammar of Afrikaans. Berlin: Mouton de Gruyter.

Halle, M. and A. Marantz. 1993. Distributed Morphology and the pieces of inflection. In K. Hale and S.J. Keyser (eds). The view from Building 20: essays in linguistics in honor of Sylvain Bromberger. Cambridge: MIT Press. pp. 111-176.

Hoekstra, T. 1999. Auxiliary selection in Dutch. Natural Language and Linguistic Theory, 17: 67-84.

Kayne, R.S. 1993. Toward a modular theory of auxiliary selection. Studia Linguistica, 47: 331.

Malherbe, D.F. 1917. Afrikaanse taalboek. Bloemfontein: De Nationale Pers Beperkt.

Merchant, J. 1999. The syntax of silence. Doctoral dissertation. Santa Cruz: University of California at Santa Cruz.

Nikolaeva, I. 2007. Introduction. In I. Nikolaeva (ed.). Finiteness: theoretical and empirical foundations. Oxford: Oxford University Press. pp. 1-19.

Ponelis, F. 1979. Afrikaanse sintaksis. Pretoria: Van Schaik. 
Ponelis, F. 1993. The development of Afrikaans. Frankfurt am Main: Peter Lang.

Robbers, K. 1997. Non-finite verbal complements in Afrikaans. Doctoral dissertation. Amsterdam: University of Amsterdam.

Schmid, T. 2005. Infinitival syntax: Infinitivus Pro Participio as a repair strategy. Amsterdam: Benjamins.

Vendryes, J. 1937. Sur líemploi de líauxiliaire avoir pour marquer le passÈ. In J.Wils, R. Meesters and W. Slijpen (eds.) Mélanges de linguistique et de philologie offerts à Jacq. van Ginneken à l'occasion du soixantième anniversaire de sa naissance. Paris: Klincksieck. pp. 85-92.

Verkuyl, H. 2008. Binary tense. Stanford: CSLI Publications.

Wiklund, A.L. 2005. The syntax of tenselessness: on copying constructions in Swedish. Doctoral dissertation. Umeå: Umeå University.

Zwart, J.W. 1996. Verb clusters in Continental West Germanic dialects. In J.R. Black and V. Motapanyane (eds). Microparametric syntax and dialect variation. Amsterdam: Benjamins. pp. 229-258.

Zwart, J.W. 2011. The syntax of Dutch. Cambridge: Cambridge University Press.

Zwart, J.W. 2014. The tense of infinitives in Dutch. In J. Hoeksema and D. Gilbers (eds). Black Book: a Festschrift in honor of Frans Zwarts. Groningen: University of Groningen. pp. 376387.

Zwart, J.W. 2018. An argument against the syntactic nature of verb movement. In L.R. Bailey and Michelle Sheehan (eds.) Order and structure in syntax volume 1: word order and syntactic structure. Berlin: Language Science Press. pp. 29-48. 